Original Research Paper

\title{
The Influence of Paddy Fields toward The Seasonal Herbaceous Wetland Ecosystem in Rawa Pening Lake
}

\author{
Desti Christian Cahyaningrum* \\ Fakultas Biologi, Universitas Kristen Satya Wacana, Salatiga, Indonesia.
}

\author{
Article History \\ Received : June $17^{\text {th }}, 2020$ \\ Revised : June $28^{\text {th }}, 2020$ \\ Accepted : June $30^{\text {th }}, 2020$ \\ Published : July $02^{\text {th }}, 2020$ \\ *Corresponding Author: \\ Desti C.Cahyaningrum, \\ Fakultas Biologi \\ Universitas Kristen Satya \\ Wacana, Salatiga, Indonesia; \\ Email: \\ desti.cahyaningrum@uksw.edu
}

\begin{abstract}
Most of the tidal land in the lakeside of Rawa Pening is currently used for rice farming activities. This activity is thought to have negative impacts on seasonal herbaceous wetland ecosystem in this region. The study aimed to analyze the influence paddy fields toward the seasonal herbaceous wetland ecosystems in Rawa Pening Lake through an vegetation composition and structure approach. This study is a quantitative descriptive research with field observation method. Data of vegetation was collected using line intercept transect technique in the area widely of $625 \mathrm{~m}^{2}$ for each affected and unaffected ecosystem sample. Data analysis was performed by calculating the Sorensen Similarity Index (IS), the Margalef Diversity Index (R), the Shanon-Wiener Diversity Index $\left(\mathrm{H}^{\prime}\right)$, the Dominance Index $(\mathrm{C})$, and the Evenness Index $(\mathrm{E})$. The results showed that there were differences in the composition and structure of vegetation on the two ecosystem samples, seen from the value of similarity index (IS) between both of them that included in the low criteria $(39.85 \%)$. The results also showed that the Shanon-Wiener Diversity Index $\left(\mathrm{H}^{\prime}\right)$ and the Margalef Diversity Index (R) on the affected ecosystem sample $\left(\mathrm{H}^{\prime}=1,9834\right.$; $\mathrm{R}=1,825)$ are lower when compared to the unaffected ecosystem sample $\left(H^{\prime}=2,1297 ; R=2,112\right)$. So it can be concluded that the existence of paddy fields has changed the composition and structure of vegetation and reduced the diversity of vegetation in the affected ecosystem. Based on these conclusions, it is recommended to construct a sustainable management system of paddy fields on Rawa Pening Lake's tidal land as the effort for natural ecosystems maintenance in this region, especially in the biodiversity and ecological services preservation.
\end{abstract}

Key words: tidal land, vegetation, similarity index, diversity, line intercept transect

\section{Pendahuluan}

Danau merupakan salah satu sumber daya yang bersifat open access. Sumber daya dengan karakteristik terbuka (open access) biasanya rentan terhadap eksploitasi yang mengarah pada degradasi lingkungan. Eksploitasi tersebut umumnya terjadi akibat konflik kepentingan yang cenderung mengutamakan manfaat ekonomi tanpa memperhatikan dampak ekologis dalam pemanfaatan lahan. Padahal, degradasi lingkungan dapat menyebabkan bencana ekologi yang pada akhirnya akan membawa masalah perekonomian bagi masyarakat sekitar.

Salah satu bentuk pemanfataan lahan yang dapat menimbulkan degradasi lingkungan pada ekosistem danau adalah kegiatan pertanian eksploitatif. Berdasarkan hasil penelitian, kegiatan pertanian di sekitar Danau Buyan telah menyebabkan status trofik danau tersebut berada dalam kategori mesotrofik (Nopiantari, Arthana \& Astarini, 2017). Hal serupa juga terjadi pada Danau Merdada. Kusumawati et al. (2010) menyebutkan bahwa residu limbah pertanian kentang telah mencemari Danau Merdada dan menyebabkan status trofik danau tersebut termasuk dalam kategori hipertrofik. Kondisi mesotrofik dan hipertrofik mengindikasikan telah terjadinya degradasi ekosistem yang mengarah pada peristiwa eutrofikasi danau.

Permasalahan serupa diduga telah terjadi di kawasan Danau Rawa Pening, Kabupaten Semarang, Jawa Tengah. Sittadewi (2008) menyebutkan bahwa di kawasan Danau Rawa Pening terdapat lahan pasang surut seluas 1.030,51 Hektar yang sebagian besar dimanfaatkan oleh penduduk sekitar untuk aktivitas 
pertanian padi. Pemanfaatan lahan pasang surut Danau Rawa Pening sebagai lahan persawahan telah meningkatkan perekonomian masyarakat. Akan tetapi, pemanfaatan lahan tersebut diduga dapat menyebabkan degradasi lingkungan yang akan mengancam keberlanjutan ekosistem Danau Rawa Pening secara keseluruhan. Degradasi lingkungan yang dikawatirkan terjadi antara lain perluasan daerah pasang surut (zona litoral) yang mengarah pada pendangkalan dan penyempitan luasan danau (zona limnetik), masuknya unsur hara ke badan perairan akibat aktivitas pertanian yang meningkatkan kecepatan eutrofikasi danau, serta meningkatkan kadar keasaman lahan akibat pelapukan bahan organik serta pencucian berbagai bahan kimia yang digunakan dalam kegiatan pertanian. Kekawatiran tersebut didukung oleh hasil penelitian terhadap sampel air danau yang menunjukkan bahwa Danau Rawa Pening berada dalam kondisi mesotrofik berdasarkan kandungan total fosfornya, serta berada dalam kondisi eutrofik berdasarkan kandungan total nitrogennya (Soeprobowati \& Suedy, 2010). Kajian mengenai dampak aktivitas pertanian terhadap status trofik Danau Rawa Pening telah banyak dilakukan. Meskipun demikian, dampak secara langsung terhadap ekosistem alami di lahan pasang surut tersebut belum banyak dikaji. Secara ekologis, lahan pasang surut Danau Rawa Pening yang dimanfaatkan sebagai lahan pertanian padi merupakan ekosistem lahan basah herba musiman.

Lahan basah herba musiman (Seasonal Herbaceous Wetland atau disingkat SHW) merupakan lahan basah air tawar yang secara periodik tergenang oleh air hujan. SHW biasanya ditemukan di daerah yang memiliki tanah relatif subur, berada pada ketinggian kurang dari 500 meter di atas permukaan laut, dan memiliki curah hujan tahunan rata-rata sebesar 400-800 mm (Bayes and Cook, 2000). Ekosistem tersebut berperan dalam berbagai hal, diantaranya: a.) konservasi tanah dan air, b.) mitigasi banjir, c.) mencegah pemanasan iklim lokal, d.) meningkatkan kualitas air, e.) habitat penting bagi keanekaragaman hayati berupa asosiasi hewan dan tumbuhan yang hidup di dalamnya secara permanen maupun yang hanya memanfatkan sumber daya dalam ekosistem tersebut secara temporer, f.) pengelolaan hama, g.) penyimpan air tanah pada musim kemarau serta merupakan perlindungan alami dari kekeringan bagi keanekaragaman hayati di kawasan tersebut. Mengingat berbagai jasa lingkungan yang dimiliki, maka keberadaan ekosistem lahan basah herba musiman secara tidak langsung juga turut berperan terhadap kelestarian ekosistem Danau Rawa Pening secara keseluruhan.
Gong et al. (2015) menyebutkan bahwa salah satu komponen yang krusial dalam ekosistem adalah tumbuhan. Tumbuhan memiliki peran yang signifikan dalam memelihara keseimbangan ekologi, yaitu sebagai penyedia makanan, habitat hewan, serta mempertahankan biodiversitas alami. Oleh karena itu, penelitian bertujuan untuk menganalisis pengaruh keberadaan persawahan terhadap ekosistem lahan basah herba musiman di Danau Rawa Pening melalui pendekatan analisis vegetasi.

\section{Bahan dan Metode}

\section{Waktu dan Lokasi penelitian}

Penelitian dilakukan pada Bulan Juni-Agustus 2019 di lahan pasang surut Danau Rawa Pening yang terletak di Desa Calombo, Kelurahan Lopait, Kecamatan Tuntang, Kabupaten Semarang, Jawa Tengah. Pemilihan lokasi sampel untuk pengambilan data dilakukan dengan teknik purposive random sampling, yaitu lahan pasang surut yang berbatasan langsung dengan lahan persawahan sebagai sampel ekosistem terdampak, serta lahan pasang surut yang terpisah sejauh 25 meter dari lahan persawahan sebagai sampel ekosistem tidak terdampak. Kedua lokasi berada dalam posisi vertikal yang relatif sama terhadap Danau Rawa Pening.

\section{Teknik Pengambilan Data}

Penelitian ini merupakan penelitian deskriptif kuantitatif dengan metode observasi lapangan. Pengambilan data vegetasi dilakukan dengan teknik line intercept transect (Setiadi, Muhadiono, \& Ayip, 2001; Tiner 2017). Luas wilayah pengambilan data pada sampel ekosistem terdampak maupun sampel ekosistem tidak terdampak masing-masing seluas $625 \mathrm{~m}^{2}$. Pada setiap sampel ekosistem, dibuat garis dasar (baseline) yang sejajar dengan tepi danau sepanjang 25 meter sebagai titik tolak garis transek. Garis transek kemudian dibentangkan sepanjang 25 meter dengan arah tegak lurus dari baseline (Gambar 1). Terdapat 6 garis transek yang dibentangkan dari baseline, sehingga jarak antar transek adalah 5 meter. Setiap transek dibagi menjadi 5 interval untuk memudahkan pengamatan, sehingga panjang setiap interval adalah 5 meter. Tumbuhan yang tersentuh oleh garis transek (individu/populasi yang diperhitungkan) kemudian diidentifikasi, dihitung jumlah individu setiap jenis dan jumlah interval yang diduduki setiap jenis, serta diukur panjang garis transek yang terpotong oleh setiap individu (intercept) serta lebar tajuk maksimal yang diproyeksikan ke dalam transek. 


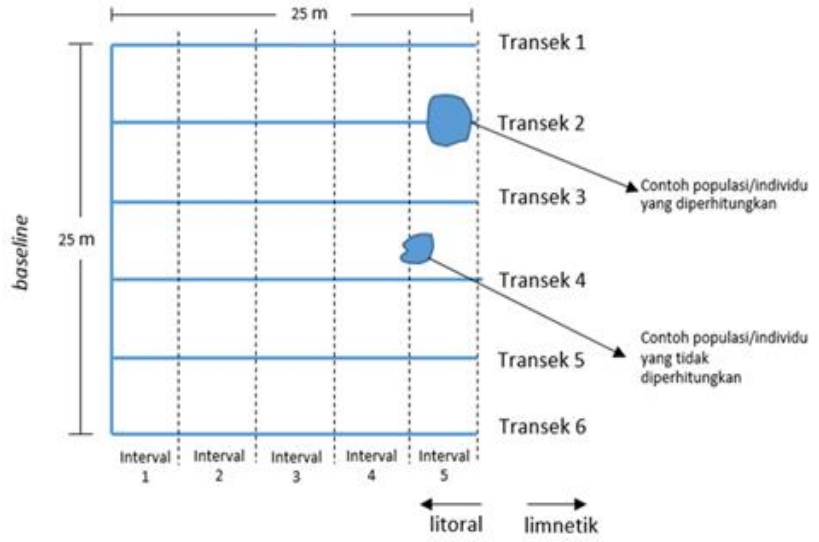

Gambar 1. Ilustrasi metode Line Intercept Transect dalam penelitian (sumber: dok. penulis)

\section{Analisis Data}

Data yang didapatkan, kemudian digunakan untuk menghitung berbagai parameter analisis vegetasi yang meliputi Kerapatan (K), kerapatan Relatif (KR), Frekuensi (F), Frekuensi Relatif (FR), Dominansi (D), Dominansi Relatif (DR), Indeks Nilai Penting (INP), Indeks Similaritas Sorensen (IS), Indeks Kekayaan Jenis Margalef (R), Indeks Keanekaragaman Shanon-Wiener (H'), Indeks Dominansi (C), dan Indeks Kemerataan Jenis (E) (Setiadi et al., 2001; Bakus, 2007; Budiwan, Fahrizal, \& Hari, 2018; Nurkhotimah, Agus, \& Titik, 2017; Odum, 1993; Nuraina, Fahrizal \& Hari, 2018).

\section{Hasil dan Pembahasan}

\section{Dampak terhadap Komposisi dan Struktur Vegetasi}

Komposisi tumbuhan pada kedua lokasi pengamatan cukup beragam. Terdapat 14 spesies tumbuhan yang ditemukan di lahan yang berbatasan langsung dengan persawahan di lahan pasang surut Danau Rawa Pening (sampel ekosistem terdampak). Pada ekosistem terdampak, spesies yang memiliki Indeks Nilai Penting (INP) tetinggi adalah Ludwigia sp., yaitu sebesar $126 \%$. Sedangkan tumbuhan dengan INP terendah adalah Ammannia sp. dan Oxalis sp., yaitu 0,9\% untuk kedua spesies tersebut (Tabel 1).

Sementara itu, komposisi tumbuhan pada ekosistem tidak terdampak terdiri atas 17 spesies tumbuhan (Tabel 2). Nilai INP tertinggi pada komunitas tumbuhan di lokasi tersebut adalah spesies Echinochloa sp., yaitu sebesar 101,46\% dan nilai INP terendah adalah spesies Urochloa mutica, yaitu sebesar $1,11 \%$. Semua spesies yang ditemukan pada ekosistem terdampak maupun tidak terdampak merupakan kelompok emergent aquatic herbs.

Indeks Nilai Penting (INP) menunjukkan kedudukan ekologis atau dominansi suatu spesies tumbuhan tertentu terhadap tumbuhan jenis lain dalam komunitasnya. Sehingga berdasarkan nilai INP tersebut, diketahui bahwa Ludwigia sp. (Gambar 2a) merupakan spesies tumbuhan yang paling mampu beradaptasi pada ekosistem terdampak dan mendominasi lingkungan. Sedangkan pada ekosistem tidak terdampak, Echinochloa sp. (Gambar 2b) merupakan spesies tumbuhan yang paling mampu beradaptasi dan mendominasi.

Tabel 1. Komposisi dan struktur vegetasi di ekosistem terdampak (data primer)

\begin{tabular}{lllccccccc}
\hline No & Suku & Spesies & K & $\begin{array}{c}\text { KR } \\
(\boldsymbol{\%})\end{array}$ & F & $\begin{array}{c}\text { FR } \\
(\boldsymbol{\%})\end{array}$ & $\begin{array}{c}\text { D } \\
\text { DR }\end{array}$ & $\begin{array}{c}\text { INP } \\
(\boldsymbol{\%})\end{array}$ \\
\hline 1 & Lythraceae & Ammannia sp. & 0,0067 & 0,08 & 0,03 & 0,80 & 0,0002 & 0,04 & 0,92 \\
2 & Cyperaceae & Cyperus rotundus $L$. & 1,2000 & 14,53 & 0,63 & 15,20 & 0,0217 & 6,17 & 35,91 \\
3 & Onagraceae & Ludwigia sp. & 4,7933 & 58,07 & 0,60 & 14,40 & 0,1883 & 53,53 & 126,01 \\
4 & Poaceae & Echinochloa sp. & 0,1867 & 2,26 & 0,40 & 9,60 & 0,0213 & 6,06 & 17,92 \\
5 & Poaceae & Hemarthria altissima & 0,2000 & 2,42 & 0,26 & 6,40 & 0,0072 & 2,06 & 10,88 \\
6 & Convolvulaceae & Ipomoea aquatica & 0,4067 & 4,92 & 0,36 & 8,80 & 0,0068 & 1,93 & 15,66 \\
7 & Onagraceae & Ludwigia leptocarpa & 0,3467 & 4,20 & 0,50 & 12,00 & 0,0706 & 20,08 & 36,28 \\
8 & Onagraceae & Ludwigia repens & 0,2667 & 3,23 & 0,40 & 9,60 & 0,0025 & 0,70 & 13,53 \\
9 & Fabaceae & Mimosa pudica & 0,0867 & 1,05 & 0,13 & 3,20 & 0,0021 & 0,61 & 4,86 \\
10 & Menyanthaceae & Nymphoides indica & 0,2000 & 2,42 & 0,30 & 7,20 & 0,0027 & 0,75 & 10,38 \\
11 & Poaceae & Oryza sativa & 0,1267 & 1,53 & 0,33 & 8,00 & 0,0117 & 3,33 & 12,86 \\
12 & Oxalidaceae & Oxalis sp. & 0,0067 & 0,08 & 0,03 & 0,80 & 0,0001 & 0,03 & 0,91 \\
13 & Poaceae & Panicum repens & 0,1467 & 1,77 & 0,10 & 2,40 & 0,0054 & 1,54 & 5,72 \\
14 & Cyperaceae & Cyperus halpan & 0,2800 & 3,39 & 0,06 & 1,60 & 0,01 & 3,12 & 8,12 \\
\hline
\end{tabular}


Tabel 2. Komposisi dan struktur vegetasi di ekosistem tidak terdampak (data primer)

\begin{tabular}{cllccccccc}
\hline No & Suku & Spesies & K & $\begin{array}{c}\text { KR } \\
(\boldsymbol{\%})\end{array}$ & $\mathbf{F}$ & $\begin{array}{c}\text { FR } \\
(\boldsymbol{\%})\end{array}$ & D & $\begin{array}{c}\text { DR } \\
(\boldsymbol{\%})\end{array}$ & $\begin{array}{c}\text { INP } \\
(\boldsymbol{\%})\end{array}$ \\
\hline 1 & Onagraceae & Ludwigia adscendens & 0,007 & 008 & 0,03 & 1,03 & 0,22 & 0,63 & 1,75 \\
2 & Cyperaceae & Cyperus rotundus & 0,447 & 5,52 & 0,23 & 7,21 & 6,62 & 19,16 & 31,90 \\
3 & Cyperaceae & Cyperus sp. & 0,027 & 0,33 & 0,07 & 2,06 & 0,02 & 0,05 & 2,44 \\
4 & Onagraceae & Ludwigia sp. & 0,740 & 9,14 & 0,23 & 7,21 & 6,57 & 19,01 & 35,37 \\
5 & Poaceae & Echinochloa sp. & 4,600 & 56,83 & 0,70 & 21,64 & 7,94 & 22,97 & 101,46 \\
6 & Asteraceae & Eclipta prostrata L & 0,167 & 2,06 & 0,20 & 6,18 & 0,15 & 0,43 & 8,68 \\
7 & Balsaminaceae & Impatiens sp. & 0,007 & 0,08 & 0,03 & 1,03 & 0,07 & 0,19 & 1,30 \\
8 & Convolvulaceae & Ipomoea aquatica & 0,500 & 6,18 & 0,40 & 12,37 & 6,07 & 17,56 & 36,11 \\
9 & Onagraceae & Ludwigia leptocarpa & 0,127 & 1,56 & 0,23 & 7,21 & 1,91 & 5,53 & 14,31 \\
10 & Onagraceae & Ludwigia peruviana & 0,033 & 0,41 & 0,16 & 5,15 & 1,62 & 4,69 & 10,26 \\
11 & Marsileaceae & Marsilea crenata & 0,020 & 0,24 & 0,03 & 1,03 & 0,50 & 1,44 & 2,72 \\
12 & Fabaceae & Aeschynomene indica & 0,013 & 0,16 & 0,03 & 1,03 & 0,01 & 0,03 & 1,22 \\
13 & Menyanthaceae & Nymphoides indica & 0,167 & 2,06 & 0,30 & 9,27 & 2,47 & 7,16 & 18,50 \\
14 & Poaceae & Oryza sativa & 0,080 & 0,99 & 0,23 & 7,21 & 0,04 & 0,11 & 8,31 \\
15 & Poaceae & Phragmites karka & 1,153 & 14,25 & 0,30 & 9,27 & 0,33 & 0,97 & 24,50 \\
16 & Poaceae & Urochloa mutica & 0,007 & 0,08 & 0,03 & 1,03 & 0,001 & 0,004 & 1,11 \\
\hline
\end{tabular}

a.

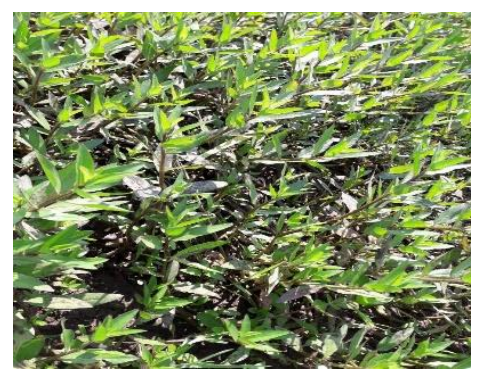

b.

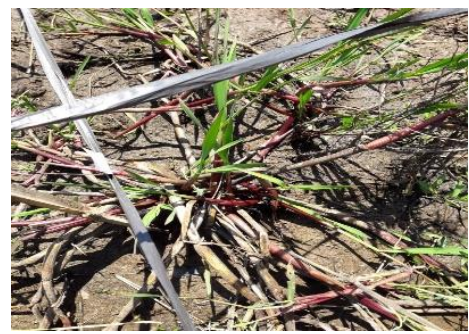

Gambar 2. Tumbuhan dengan INP tertinggi pada ekosistem terdampak dan tidak terdampak a.) Ludwigia sp. b.) Echinochloa $s p$. (sumber: dok. penulis)

Berdasarkan nilai INP pada setiap spesies, nilai Indeks similaritas (IS) kedua ekosistem yang sedang dibandingkan termasuk dalam kategori rendah yaitu sebesar 39,85\%. Hasil tersebut relatif sama dengan perhitungan IS menggunakan pendekatan jumlah spesies, yaitu sebesar $38,46 \%$ yang juga tergolong dalam kategori rendah. Menurut Oktaviani (2012), IS < 50\% termasuk dalam kategori similaritas rendah sedangkan IS > 50\% termasuk dalam kategori similaritas tinggi. Indeks similaritas menunjukkan tingkat kemiripan komposisi dan struktur antar komunitas tumbuhan. Oleh karena itu, nilai
IS yang diperoleh mengindikasikan bahwa komposisi dan struktur spesies yang menyusun komunitas tumbuhan di ekosistem terdampak berbeda dengan ekosistem tidak terdampak. Menurut Barbour et al. (1987), suatu lingkungan mikro (mikrositus) yang relatif homogen akan dikoloni oleh spesies yang sama, akibat mekanisme adaptasi dan toleransi terhadap kondisi habitat tersebut yang telah berkembang secara alami. Berdasarkan pendapat tersebut, diduga bahwa lingkungan mikro pada ekosistem yang terdampak telah mengalami perubahan akibat keberadaan persawahan. Akibatnya, spesies tumbuhan yang mampu beradaptasi dan berkembang di ekosistem terdampak berbeda dengan ekosistem yang belum terdampak. Karena semestinya pada lingkungan mikro yang relatif sama, akan dapat diadaptasi oleh individu yang sama.

Perubahan lingkungan dapat terjadi akibat adanya perbedaan kondisi lingkungan secara kimia, fisik, maupun interaksi antar spesies di sepanjang gradien lokasi pengamatan (Setiadi, 2004). Kedua lokasi pengamatan pada penelitian ini relatif sama secara geografis. Kedua lokasi tersebut terletak pada posisi vertikal yang relatif sama terhadap Danau Rawa Pening. Ekosistem terdampak berbatasan langsung dengan persawahan, sedangkan ekosistem tidak terdampak berjarak sejauh 25 meter dari persawahan (Gambar 3). Oleh karena itu, kemungkinan adanya variasi fisik akibat letak geografis cenderung tidak signifikan. Selain itu, lokasi pengamatan berada di lahan pasang surut Danau Rawa Pening dan keduanya termasuk tipe ekosistem lahan basah herba musiman. Sehingga, perubahan lingkungan mikro pada lokasi terdampak diduga terjadi akibat perubahan kimia yang mengarah pada perubahan interaksi antar spesies. Menurut Munir (1987), tanah yang yang diolah menjadi sawah dengan kondisi tergenang dan dikeringkan secara bergantian 
seperti pada lokasi pengamatan, akan mengalami perubahan kandungan mineral. Kandungan mineral pada tanah persawahan lebih rendah dibandingkan tanah secara umum. Selain itu, Prasetyo et al. (2004) menyebutkan bahwa pengolahan tanah dan pengendalian gulma pada lahan persawahan telah merusak keseimbangan komunitas alami yang mengarah pada terbentuknya struktur komunitas khusus sawah.

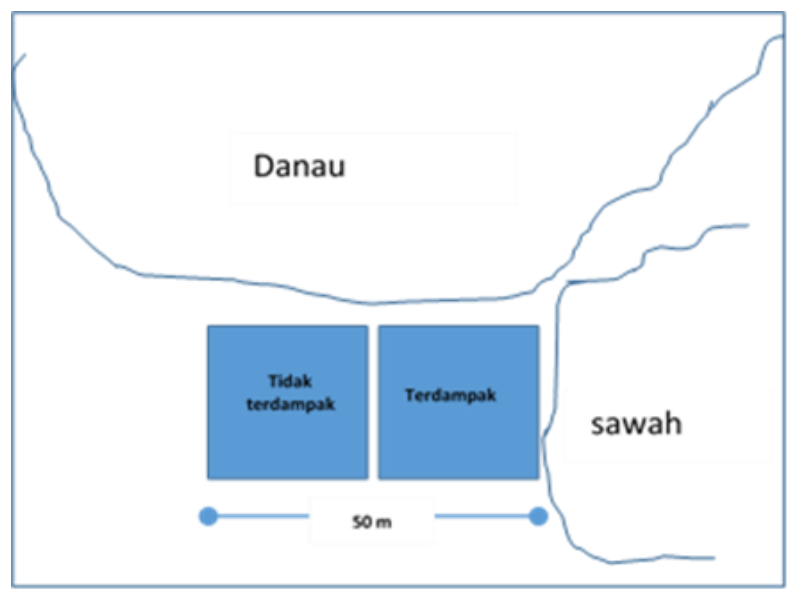

Gambar 3. Posisi relatif lokasi pengamatan terhadap danau dan persawahan (sumber: dok. penulis)

\section{Dampak terhadap Keanekaragaman Vegetasi}

Perubahan lingkungan pada ekosistem terdampak, juga menyebabkan berkurangnya jumlah spesies yang dapat beradaptasi di lingkungan tersebut. Pada ekosistem terdampak terdapat 14 spesies tumbuhan, sedangkan di ekosistem tidak terdampak ditemukan lebih banyak spesies tumbuhan yaitu sebanyak 17 jenis. Hal ini sejalan dengan hasil analisis menggunakan pendekatan indeks kekayaan jenis (R). Indeks kekayaan jenis pada ekosistem terdampak adalah 1,825; lebih kecil dibanding indeks kekayaan jenis pada ekosistem tidak terdampak, yaitu sebesar 2,112. Menurut Ura' et al. (2017), Indeks kekayaan jenis > 5 tergolong tinggi, antara 3,5 - 5 tergolong sedang, dan $<3,5$ tergolong rendah. Berdasarkan kriteria tersebut, maka kedua ekosistem berada pada kategori kekayaan jenis rendah.

Selanjutnya, Indeks keanekaragaman dapat memberikan gambaran lebih lanjut mengenai komposisi tumbuhan pada kedua ekosistem yang diamati. Indeks keanekaragaman (H') pada ekosistem terdampak adalah sebesar 1,9834 sedangkan pada ekosistem tidak terdampak adalah 2,1297. Menurut Supriadi et al. (2015), nilai H'> 3,0 mengindikasikan tingginya tingkat keanekaragaman spesies pada suatu ekosistem. Sementara itu nilai $2,0 \leq \mathrm{H}$ ' $\leq 3,0$ menunjukkan bahwa keanekaragaman yang dimiliki berada pada kategori sedang. Keanekaragaman jenis rendah apabila nilai $H^{\prime} \leq 2,0$. Berdasarkan kriteria tersebut, maka keanekaragaman pada ekosistem terdampak termasuk rendah dan pada ekosistem tidak terdampak termasuk sedang.

Indeks keanekaragaman dapat menunjukkan ada atau tidaknya tekanan terhadap suatu komunitas tumbuhan. Menurut Supriadi et al. (2015), tingkat keanekaragaman rendah menunjukkan adanya tekanan ekologi tinggi. Sementara itu, tingkat keanekaragaman sedang menunjukkan tekanan ekologi sedang. Sebaliknya, tingkat keanekaragaman tinggi menunjukkan bahwa komunitas tersebut stabil dan memiliki tekanan ekologi yang rendah. Berdasarkan data tersebut, dapat diindikasikan bahwa keberadaan persawahan menimbulkan tekanan ekologi sehingga ekosistem terdampak memiliki indeks keanekaragaman yang rendah. Sementara itu, tekanan ekologi pada ekosistem tidak terdampak relatif lebih rendah sehingga memiliki tingkat keanekaragaman tumbuhan yang lebih baik dibanding ekosistem terdampak, yaitu dalam kategori sedang.

Sirait et al. (2018) menyatakan bahwa indeks keanekaragaman (H') berbanding terbalik dengan indeks dominansi (C). Artinya semakin kecil indeks keanekaragaman suatu komunitas, menandakan adanya dominansi dari satu atau beberapa jenis spesies dan berlaku sebaliknya. Pada penelitian ini, hasil analisis melalui parameter indeks dominansi sejalan dengan pernyataan tersebut. Indeks dominansi (C) pada sampel ekosistem terdampak adalah 0,21945, sedangkan pada sampel ekosistem tidak terdampak adalah 0,1698. Terlihat bahwa indeks dominansi pada ekosistem terdampak relatif lebih tinggi dibanding ekosistem tidak terdampak. Hasil tersebut menunjukkan bahwa indeks dominansi pada kedua lokasi pengamatan berbanding terbalik dengan indeks keanekaragamannya.

Kesimpulan tersebut semakin diperkuat dengan indeks kemerataan jenis (E). Besarnya indeks kemerataan ditentukan oleh persebaran setiap jenis tumbuhan pada suatu komunitas. Semakin merata persebaran spesies tumbuhan, maka akan semakin tinggi nilai kemerataannya. Sebaliknya apabila terdapat tumbuhan yang dominan sehingga persebaran spesies menjadi tidak merata, maka indeks kemerataan jenis dalam komunitas tersebut akan semakin rendah (Arrijani, Dede, \& Ibnul, 2006). Hasil perhitungan indeks kemerataan jenis dalam penelitian ini sejalan dengan pernyataan tersebut. Nilai E pada ekosistem terdampak adalah 0,751, sedangkan pada ekosistem tidak terdampak adalah 0,7681. Ekosistem terdampak yang memiliki nilai $\mathrm{C}$ relatif lebih tinggi menunjukkan nilai E yang lebih rendah. Sebaliknya, ekosistem tidak terdampak yang memiliki nilai E relatif lebih tinggi, menunjukkan nilai $\mathrm{C}$ yang lebih rendah dibanding ekosistem terdampak. Meskipun demikian, kedua ekosistem tersebut memiliki nilai $\mathrm{C}$ yang berkisar antara 0 - 0,5 dan masih tergolong dalam dominansi rendah. Sedangkan indeks kemerataan keduanya, berada di 
kisaran 0,75-1 yang termasuk dalam kriteria keseragaman tinggi (Supriadi et al., 2015). Kedua hal tersebut menunjukkan bahwa kedua ekosistem berada dalam kondisi lingkungan yang masih relatif stabil.

\section{Kesimpulan}

Melalui pendekatan analisis vegetasi, disimpulkan bahwa keberadaan persawahan telah merubah komposisi dan struktur vegetasi, serta mengurangi keanekaragaman vegetasi pada sampel ekosistem terdampak. Secara lebih luas, disimpulkan bahwa keberadaan persawahan menyebabkan degradasi terhadap ekosistem alami di lahan pasang surut Danau Rawa Pening yang termasuk dalam kategori ekosistem lahan basah herba musiman. Oleh karena itu, direkomendasikan untuk melakukan kajian lebih lanjut mengenai dampak persawahan sebagai dasar perumusan suatu sistem pengelolaan berkelanjutan terhadap aktivitas pertanian padi di lahan pasang surut Danau Rawa Pening. Sistem pengelolaan berkelanjutan menjadi semakin penting, mengingat masifnya aktivitas pertanian padi di tepian Danau Rawa Pening yang dikawatirkan akan semakin mengancam biodiversitas serta jasa lingkungan yang dimiliki oleh ekosistem alami di kawasan tersebut.

\section{Ucapan Terima kasih}

Terima kasih disampaikan kepada Bapak Rully Adi Nugroho, Ph.D., atas berbagai masukan terhadap penelitian ini. Ucapan terima kasih juga disampaikan kepada Bapak Anggara Mahardika, S.Si., M.Si., M.Sc., Ph.D., serta mahasiswa Magister Biologi Universitas Kristen Satya; Wacana Vita De Vita, Vanessa Dora Salawane, Fidel A.M.Kolin, Yohanis Beanal, dan Ereminas Nirigi yang telah membantu di lapangan.

\section{Referensi}

Arrijani, S. D., Guhardja, E. \& Qayim, I. (2006). Analisis vegetasi hulu DAS Cianjur Taman Nasional Gunung Gede Pangrango. Biodiversitas, 7(2), 147-153. DOI: https://doi.org/10.13057/biodiv/d070212.

Bakus, G. J. (2007). Quantitative analysis of marine biological communities: field biology and environment. John Wiley \& Sons. ISBN 0-47004440-3, pp: 36-45.

Barbour, M. G., Burk, J. H. \& Pitts, W. D. (1980). Terrestrial plant ecology. Benjamin/Cummings. ISBN 0-8053-0541-6. pp: 54.
Bayes, E. \& Cook D. (2020). Seasonal herbaceous wetlands : Identification and management handbook.

https://www.gbcma.vic.gov.au/download/?fdid=3 A143283358748FBDEC96DF130C197BA

[diakses tanggal 7 April 2020].

Budiwan, A., Fahrizal \& Hari, P. (2018). Analisa vegetasi pada pengelolaan hutan tradisional masyarakat Suku Dayak Tamambaloh dan Iban di wilayah REDD+ KPHP model Kapuas Hulu. Jurnal Hutan Lestari $\quad$,6(1):246 $\quad-\quad 253$. http://jurnal.untan.ac.id/index.php/jmfkh/article/vi ew/25403.

Gong, Z., Cui, T., Pu, R., Lin, C. \& Chen, Y. (2015). Dynamic simulation of vegetation abundance in a reservoir riparian zone using a sub-pixel Markov model. International Journal of Applied Earth Observation and Geoinformation, 35, 175-186. DOI: https://doi.org/10.1016/j.jag.2014.09.004.

Kusumawati, A., Santosa, L. W. \& Hadisusanto, S. (2010). Kajian status trofik sebagai dasar strategi penataan lingkungan di Telaga Merdada. Majalah Geografi Indonesia, 24(1), 10-25. DOI: https://doi.org/10.22146/mgi.13338.

Munir, M. (1987). Pengaruh Penyawahan terhadap Morfologi Pedogenesis, Elektrokimia dan Klasifikasi Tanah. Disertasi Non Publikasi. Institut Pertanian Bogor.

Nopiantari, N. P. V., Arthana, I. W. \& Astarini, I. A. (2017). Dampak kegiatan pertanian terhadap tingkat eutrofikasi dan jenis-jenis fitoplankton di Danau Buyan Kabupaten Buleleng Provinsi Bali. Jurnal Ecotrophic, 11(1). DOI: https://doi.org/10.24843/EJES.2017.v11.i01.p08.

Nuraina,I., Fahrizal \& Hari, P. (2018). Analisa komposisi dan keanekaragaman jenis tegakan penyusun hutan tembawang jelomuk di Desa Meta Bersatu kecamatan Sayan Kabupaten Melawi. Jurnal Hutan Lestari, 6(1):137-146. http://jurnal.untan.ac.id/index.php/jmfkh/article/vi ew/24151/75676575828.

Nurkhotimah, Agus, H. \& Titik, S. (2017). Komposisi, struktur dan keanekaragaman spesies tumbuhan di Cagar Alam Dungus Iwul Kabupaten Bogor. Media Konservasi, 22(2):138-145. DOI: https://doi.org/10.29244/medkon.22.2.138-145.

Odum, E.P. (1993). Dasar-dasar Ekologi. Terjemahan 
Tjahjono Samingan. Edisi Ketiga. Yogyakarta: Gadjah Mada University Press.

Oktaviani, I. (2012). Dinamika Komununitas Plankton di Perairan Hutan Mangrove Leuweng Sancang. Skripsi Non Publikasi. Universitas Pendidikan Indonesia.

Prasetyo, H. P., Adiningsih, J. S., Subagyono, K. \& Simanungkalit, R. D. M. (2004). Mineralogi, kimia, fisika, dan biologi lahan sawah. hlm. 29-82 dalam Tanah Sawah dan Teknologi Pengelolaannya. Pusat penelitian dan Pengembangan Tanah dan Agroklimat, Badan Litbang Pertanian. http://balittanah.litbang.pertanian.go.id/ind/doku mentasi/buku/buku\%20lahan\%20sawah/02minera 1_fisik_tanah.pdf. [diakses tanggal 7 Mei 2020].

Setiadi, D., Muhadiono, I. \& Yusron, A. (2001). Penuntun praktikum ekologi. Laboratorium Ekologi, Jurusan Biologi, FMIPA, Institut Pertanian Bogor, Indonesia, 1-152.

Setiadi, D. (2005). Keanekaragaman spesies tingkat pohon di taman wisata alam Ruteng, Nusa Tenggara Timur. Biodiversitas, 6(2), 118-122. DOI: https://doi.org/10.13057/biodiv/d060210.

Sirait, M., Rahmatia, F. \& Pattulloh, P. (2018). Komparasi indeks keanekaragaman dan indeks dominansi fitoplankton di Sungai Ciliwung Jakarta. Jurnal Kelautan, 11(1):75-79. DOI: https://doi.org/10.21107/jk.v11i1.3338
Sittadewi, E. H. (2008). Kondisi lahan pasang surut kawasan rawa pening dan potensi pemanfaatannya. Jurnal Teknologi Lingkungan, 9(3):294-301. DOI: https://doi.org/10.29122/jtl.v9i3.474.

Soeprobowati, T. R. \& Suedy, S. W. A. (2010). Status trofik danau rawapening dan solusi pengelolaannya. Jurnal Sains Dan Matematika, 18(4), 158-169. https://ejournal.undip.ac.id/index.php/sm/article/v iew/6257.

Supriadi, S., Romadhon, A. \& Farid, A. (2015). Struktur Komunitas Mangrove di Desa Martajasah Kabupaten Bangkalan. Jurnal Kelautan: Indonesian Journal of Marine Science and Technology, 8(1), 44-51. DOI: https://doi.org/10.21107/jk.v8i1.812.

Tiner, R.W. (2017). Wetland Indicator: A Guide to Wetland Formation, Identification, Delineation, Classification, and Mapping. Taylor \& Francis Group, United States. ISBN: 9781439853696.pp:264-270.

Ura', R., Samuel, A.P. \& Daud, M. (2017). Analisis vegetasi tanaman bawah berkasiat obat pada sistem Agrisivilkultur di Lembang Sereale Toraja Utara. Jurnal Ilmu Alam dan Lingkungan, 8(16):45-51. DOI: http://dx.doi.org/10.20956/jal.v8i16.2989. 